\title{
Long-Run Relationship and Causality between Foreign Direct Investment and Growth: Evidence from Ten African Countries
}

\author{
Loesse Jacques ESSO
}

\author{
Ecole Nationale Supérieure de Statistique et d'Economie Appliquée (ENSEA), Côte d'Ivoire \\ Cellule d'Analyse de Politiques Economiques du CIRES (CAPEC), Côte d'Ivoire \\ Centre Ivoirien de Recherches Economiques et Sociales (CIRES), Côte d'Ivoire \\ Tel: 225-2244-4124, Fax: 225-2244-3988. E-mail: LJ.esso@gmail.com
}

\begin{abstract}
The aim of this paper is to re-examine the relationship between foreign direct investment and economic growth in the case of ten Sub-Saharan African countries. To this end, we use two newly econometric approaches, namely the Pesaran et al. (2001) approach to cointegration and the procedure for non-causality test of Toda and Yamamoto (1995). We use data from the 2008 World Investment Report dataset of the UNCTAD, the African Development Bank (2008) and the World Bank (2008) from 1970 to 2007. We show that there is a positive long-run relationship between foreign direct investment and economic growth in Angola, Cote d'Ivoire, Kenya, Liberia, Senegal and South Africa. However, foreign direct investment significantly causes economic growth in Angola, Cote d'Ivoire and Kenya, while growth causes foreign direct investment in Liberia and South Africa.
\end{abstract}

Keywords: FDI, Growth, Cointegration, Causality, Sub-Saharan Africa

JEL Classification: C32, F21.

\section{Introduction}

Foreign direct investment (FDI) in developing countries has increased significantly over the last 25 years. Total FDI rose from some US $\$ 4$ billion in 1980, to US $\$ 182$ billion in 1999, before falling back to US $\$ 152$ billion in 2003 (Busse and Hefeker, 2007). However, the efforts by Sub-Saharan African countries to attract FDI for growth and development are far from adequate. Since 1970, FDI inflows into Sub-Saharan African countries increased modestly. Average inflows to the region is put at US\$1.9 billion in 1983-1987, US\$3.1 billion in 1988-1992, US\$6.0 billion in 1993-1997 and to \$8.3 billion in 1998-2000. FDI inflows to Sub-Saharan African countries have dropped from 11 percent in 1976-1980 to nine percent in 1985, five percent in 1991-1995 and to less than four percent in 1996-2000 (Abdulahi, 2007). Since most countries in Sub-Saharan Africa are recovering from a long stagnation after the implementation of macroeconomic reform programmes, are FDI inflows effectively important to accelerate growth rates to be able to move the majority of their people out of poverty?

The role of FDI in the growth process of both industrial and developing countries has for long been a topic of intense debate. The relationship has been studied by explaining four main channels: (i) determinants of growth, (ii) determinants of FDI, (iii) role of multi-national firms in host countries, and (iv) direction of causality between the two variables. The relationship between FDI and economic growth is one of the thorniest areas in the present debate. There is a wide spectrum of views on FDI from those who see it uncritically as contributing to economic growth in all circumstances to those, largely from the anti-globalisation movement, who conclude that FDI is pernicious to national development. FDI has many effects, which vary significantly by the sector in which the FDI is made and by the type of host country.

At the firm level, several studies provided evidence of technological spillover and improved plant productivity. At the macro level, FDI inflows in developing countries tend to crowd in other investment and are associated with an overall increase in total investment. Most studies found that FDI inflows led to higher per capita GDP, increase economic growth rate and higher productivity growth. As noted by De Mello (1997), two channels have been advanced to explain the positive impact of FDI on growth. First, through capital accumulation in the recipient country, FDI is expected to be growth-enhancing by encouraging the incorporation of new inputs and foreign technologies in the production function of the recipient economy. Second, through technology transfer, FDI is expected to increase the existing stock of knowledge in the recipient economy through labour training and skill acquisition (Borensztein et al., 1998; Mastromarco and Ghosh, 2009), on the one hand and through the introduction of alternative management practices and organization arrangements, on the other. Essentially, the extent to which FDI is growth-enhancing depends on the economic and technological conditions of the host country. For example, Borensztein et al. (1998) suggest that there is a strong complementary effect between FDI and human capital, that is, the contribution of FDI to economic growth is enhanced by its interaction with the 
level of human capital in the host country. Moreover, the magnitude of the FDI-growth link depends on the degree of complementarity and substitution between FDI and domestic investment (De Mello, 1999), and depends on institutional matters, such as the recipient economy's trade regime, legislation, political stability, urbanization rate (Hsiao and Shen, 2003), etc.

However, studies in the line of Carcovic and Levine (2003) do not lend support to the view that FDI promotes growth. Moreover, Hanson (2001) has found weak evidence that FDI generates positive spillovers for host countries. Recently, comprehensive discussions at the firm level have been provided by Gorg and Greenaway (2004).

Another strand of the literature has focused more directly on the causal relationships between FDI and growth. For example, Chowdhury and Mavrotas (2006) examines the causal relationship between FDI and economic growth by using time-series data covering the period 1969-2000 for three developing countries, namely Chile, Malaysia and Thailand. They follow the Toda and Yamamoto causality test approach. Their empirical findings clearly suggest that GDP causes FDI in the case of Chile and not vice versa, while for both Malaysia and Thailand, there is strong evidence of a bi-directional causality between the two variables. Furthermore, in Hansen and Rand (2006), the causal relationship between FDI and GDP is analysed in a sample of 31 developing countries covering the period 1970-2000. Their conclusions regarding the direction of causation between the two variables seem to vary significantly depending on the econometric approach adopted and the sample used. In addition, looking at time series on 11 countries, Zhang (2001) evidences strong Granger-causal relationship between FDI and GDP growth.

In summary, despite the truly enormous amount of research that has been undertaken on FDI there remain serious methodological issues. Moreover, probably due to relatively small level of foreign direct investment to Africa, when compared with other regions, e.g. Latin America and Asia, not many studies have been reported on the effects of FDI on economic growth.

The aim of this paper is to contribute to the empirical literature on the relationship between foreign direct investment and economic growth, for ten Sub-Saharan African countries, namely Angola, Cameroon, Congo, Cote d'Ivoire, Ghana, Kenya, Liberia, Nigeria, Senegal and South Africa. To this end, we employ two newly introduced methods in applied economics: the Pesaran et al. (2001) approach to cointegration and the Toda and Yamamoto (1995) causality procedure. The Pesaran et al. (2001) approach has at least two major advantages over the traditional approaches (Engle and Granger, Johansen) used by a wide range of studies. The first advantage is that it is applicable irrespective of whether the underlying regressors are purely stationary, purely integrated or mutually cointegrated. The second advantage is that it has superior statistical properties in small samples. The bounds test is relatively more efficient in small sample data sizes as is the case in most empirical studies on African countries. Furthermore, Toda and Yamamoto (1995) propose an interesting yet simple procedure requiring the estimation of an augmented vector autoregressive (VAR) which guarantees the asymptotic distribution of the Wald statistic, since the testing procedure is robust to the integration and cointegration properties of the process. Data are derived from UNCTAD (2008), the African Development Bank (2008) and the 2008 World Development Indicators of the World Bank (2008), and span from 1970 to 2007.

The remainder of this paper is organized as follows. Section 1 highlights the econometric framework. In the Section 2, we present the main results of this study. We finish by the conclusion.

\section{The econometric framework}

This section highlights the econometric model used to study cointegration and causality between economic growth and FDI. We use the Pesaran et al. (2001) cointegration approach and the Toda and Yamamoto (1995) causality testing procedure.

\subsection{Data and variables}

This paper uses annual time series data on ten Sub-Saharan African countries, namely, Angola, Cameroon, Congo, Cote d'Ivoire, Ghana, Kenya, Liberia, Nigeria, Senegal, and South Africa. These African countries benefit large foreign direct investment inflows and are characterized by high levels of the per capita gross domestic product during the last two decades. In addition, these countries are viewed as having strong prospects over the near term in attracting large volumes of global FDI flows because of a successful implementation of reforms. That is why this study focuses on these ten African countries. The series comprise yearly observations between 1970 and 2007, namely real gross domestic product per capita (GDPC) as a measure for economic growth and the ratio of foreign direct investment (FDI) inflows to GDP (RFDI). Data on real GDP per capita and GDP are from the 2008 World Development Indicators of the World Bank (2008) and from the Selected 
Statistics on African Countries of the African Development Bank (2008), and time series on FDI inflows come from the 2008 World Investment Report Dataset of the United Nations Conference on Trade and Development (UNCTAD, 2008).

Most African countries, since years, depend largely on the export of commodities like cocoa, coffee, rubber and mineral resources. However, efforts have been made to increase economic activity, incomes and general welfare. Economic reforms largely been aimed at attracting FDI. As part of the most African governments' effort to attract FDI, various policies and institutional structures have been developed in many countries. For instance, the Structural Adjustment Programme has undertaken from the mid 1980s through to the early 1990s was not just aimed at economic restructuring but also promoting FDI inflows. This study tries to quantify the relationship between FDI and growth and examines whether FDI is important for growth in the ten Sub-Saharan African countries considered here.

\subsection{The cointegration approach}

Econometric literature proposes different methodological alternatives to empirically analyse the long-run relationships and dynamic interactions between two or more time-series variables. The most widely used methods include the two-step procedure of Engle and Granger (1987) and the full information maximum likelihood-based approach due to Johansen (1988) and Johansen and Juselius (1990). All these methods require that the variables under investigation are integrated of order one. This inevitably involves a step of stationarity pre-testing, thus introducing a certain degree of uncertainty into the analysis. In addition, these tests suffer from low power and do not have good small sample properties (Cheung and Lai, 1993; Harris, 1995). Due to these problems, this study makes use of a newly developed approach to cointegration that has become popular in recent years.

The bounds testing approach to cointegration was originally introduced by Pesaran and Shin (1999) and further extended by Pesaran et al. (2001). The bounds testing approach to cointegration has at least two major advantages over the Johansen and Juselius (1990) approach used by a wide range of studies (Masih and Masih 2000; Narayan and Peng, 2007). The first advantage is that it is applicable irrespective of whether the underlying regressors are purely $\mathrm{I}(0)$, purely $\mathrm{I}(1)$ or mutually cointegrated. The second advantage is that it has superior statistical properties in small samples. The bounds test is relatively more efficient in small sample data sizes as is the case in most empirical studies on African countries. Estimates derived from Johansen-Juselius method of cointegration are not robust when subjected to small sample sizes such as that in the present study.

To search for possible long run relationships amongst the variables, namely gross domestic product per capita (GDPC) and the ratio of foreign direct investment to GDP, we employ the bounds testing approach to cointegration suggested by Pesaran et al. (2001). For notational simplicity, we denote by RFDI the ratio of foreign direct investment inflows to GDP. This involves estimating the following unrestricted error correction model (UECM):

$$
\Delta \ln \left(G D P C_{t}\right)=\alpha_{0}+\alpha_{1} \ln \left(G D P C_{t-1}\right)+\alpha_{2} \ln \left(R F D I_{t-1}\right)+\sum_{i=1}^{p} \beta_{i} \Delta \ln \left(G D P C_{t-i}\right)+\sum_{i=0}^{p} \gamma_{i} \Delta \ln \left(R F D I_{t-i}\right)+\varepsilon_{t}
$$

where the $\alpha_{i} \mathrm{~s}(i=0,1,2), \beta_{i} \mathrm{~s}(i=1,2, \ldots, p), \gamma_{i} \mathrm{~s}(i=0,1,2, \ldots, p)$ are the parameters of the model. The structural lags $p$ are determined by using minimum Akaike (AIC) and Schwarz Bayesian (SC) information criteria.

To depict the presence of cointegration the estimated coefficients of lagged level variables are restricted equal to zero. Thus the null hypothesis for no cointegration between GDP per capita and the ratio of FDI to GDP according to equation (1) is:

$$
H_{0}: \alpha_{1}=\alpha_{2}=0
$$

The F-test statistic has a non-standard distribution which depends upon (i) whether variables included in the autoregressive distributed lags (ARDL) model are I(0) or I(1), (ii) the number of regressors, (iii) whether the ARDL model contains an intercept and/or a trend, and (iv) the sample size. Thus, the computed F-statistic is compared with two asymptotic critical values tabulated by Pesaran et al. (2001) or Narayan (2005) for sample sizes ranging from 30 observations to 80 observations. The lower critical value assumes that all the regressors are $\mathrm{I}(0)$, while the upper critical value assumes that they are I(1). Therefore, if the computed F-statistic is greater than the upper critical value, the null of no cointegration is rejected and we conclude that the ratio of FDI to GDP and the real GDP per capita share a long-run level relationship. If the calculated F-statistic is below the lower critical value, then the null hypothesis of no cointegration cannot be rejected regardless of the orders of 
integration of the variables. On the other hand, if it falls inside the critical values bounds, the test is inconclusive unless we know the order of integration of the underlying variables.

If a cointegration relationship is observed between the series, Bardsen (1989) method will be used to compute the short and long run coefficients. From the estimation of (1), the long-run coefficient is computed as the coefficient of the one lagged level explanatory variable divided by the coefficient of the one lagged level dependent variable and then multiplies with a negative sign. Thus, under the alternative of interest $\alpha_{1} \neq 0$ and $\alpha_{2} \neq 0$, the long-run level relationship between the real GDP per capita (GDPC) and the ratio of FDI to GDP (RFDI) is described as follows:

$$
\ln \left(G D P C_{t}\right)=\vartheta_{0}+\vartheta_{1} \ln \left(R F D I_{t}\right)+\omega_{t}
$$

where $\vartheta_{0}=-\frac{\alpha_{0}}{\alpha_{1}}$ and $\vartheta_{1}=-\frac{\alpha_{2}}{\alpha_{1}}$, and $\omega_{t}$ is a stationary process with mean zero.

\subsection{The causality analysis}

The Granger causality test is conventionally conducted by estimating vector autoregressive (VAR) models. Based upon the Granger Representation Theorem, Granger (1986) shows that if a pair of I(1) series are cointegrated there must be a unidirectional causation in either way. If the series are not I(1), or are integrated of different orders, no test for a long run relationship is usually carried out. However, given that unit root and cointegration tests have low power against the alternative, these tests can be inappropiate and can suffer from pre-testing bias. If the data are integrated but not cointegrated, then causality tests can be conducted by using the first differenced data to achieve stationarity. Granger non-causality test in an unrestricted VAR model can be simply conducted by testing whether some parameters are jointly zero, usually by a standard Wald statistic (or F-statistic). Phillips and Toda (1993) show that the asymptotic distribution of the test in the unrestricted case involves nuisance parameters and nonstandard distributions. An alternative procedure to the estimation of an unrestricted VAR consists of transforming an estimated error correction model (ECM) into levels VAR form and then applying the Wald type test for linear restrictions. Toda and Yamamoto (1995) propose an interesting yet simple procedure requiring the estimation of an augmented VAR which guarantees the asymptotic distribution of the Wald statistic (an asymptotic $\chi^{2}$-distribution), since the testing procedure is robust to the integration and cointegration properties of the process.

We use a bivariate VAR $\left(m+d_{\max }\right)$ comprised of GDP per capita and the ratio of foreign direct investment inflows to GDP, following Yamada (1998), and examine the non-causality between FDI and economic growth:

$$
\begin{gathered}
Y_{t}=\varphi_{0}+\sum_{i=1}^{m} \psi_{i} Y_{t-i}+\sum_{i=m+1}^{m+d_{\max }} \psi_{i} Y_{t-i}+\sum_{i=1}^{m} \varphi_{i} F_{t-i}+\sum_{i=m+1}^{m+d_{\max }} \varphi_{i} F_{t-i}+v_{1 t} \\
F_{t}=\chi_{0}+\sum_{i=1}^{m} \eta_{i} F_{t-i}+\sum_{i=m+1}^{m+d_{\max }} \eta_{i} F_{t-i}+\sum_{i=1}^{m} \chi_{i} Y_{t-i}+\sum_{i=m+1}^{m+d_{\max }} \chi_{i} Y_{t-i}+v_{2 t}
\end{gathered}
$$

where $Y_{t}=\ln \left(G D P C_{t}\right), F_{t}=\ln \left(R F D I_{t}\right), \varphi_{i} \mathrm{~s}, \psi_{i} \mathrm{~s}, \eta_{i} \mathrm{~s}$, and $\chi_{i} \mathrm{~s}$ are the parameters of the model; $d_{\max }$ is the maximum order of integration suspected to occur in the system; $v_{1 t} \sim N\left(0, \Sigma_{v 1}\right)$ and $v_{2 t} \sim N\left(0, \Sigma_{v 2}\right)$ are the residuals of the model and $\Sigma_{v 1}$ and $\Sigma_{v 2}$ the covariance matrices of $v_{1 t}$ and $v_{2 t}$, respectively.

The null of non-causality from FDI to growth can be expressed as $H_{0}: \varphi_{i}=0, \forall i=1,2, \ldots, m$. Let $\varphi=\operatorname{vec}\left(\varphi_{1}, \varphi_{2}, \ldots, \varphi_{m}\right)$ be the vector of the first $m$ VAR coefficients. For a suitable chosen $R$, the Modified Wald Statistic for testing $H_{0}$ is:

$$
W=T\left(\hat{\varphi}^{\prime} R^{\prime}\left(R \hat{\Sigma}_{v} R^{\prime}\right)^{-1} R \hat{\varphi}\right)
$$

where $\hat{\varphi}$ is the ordinary least squares estimate for the coefficient $\varphi$ and $\hat{\Sigma}_{v}$ is a consistent estimate for the asymptotic covariance matrix of $\sqrt{T}(\hat{\varphi}-\varphi)$. The test statistic is asymptotically distributed as a $\chi^{2}$ with $m$ degrees of freedom. 
Two steps are involved with implementing the procedure. The first step includes the determination of the lag length $(m)$ and the second one is the selection of the maximum order of integration $\left(d_{\max }\right)$ for the variables in the system. Measures such as the Akaike Information Criterion (AIC), Schwarz Information Criterion (SC), Final Prediction Error (FPE) and Hannan-Quinn (HQ) Information Criterion can be used to determine the appropriate lag order of the VAR. In this paper, we use Akaike Information Criterion (AIC) and Schwarz Information Criterion (SC) to select the optimal lag to include in models. We use the Augmented Dickey-Fuller tests to determine the maximum order of integration.

\section{The empirical results}

While the bounds test for cointegration is applicable irrespective of whether the variables are integrated of order one or order zero, it is important to establish that the variables are not integrated of an order higher than one. Our second reason for conducing unit root tests is to determine the extra lags to be added to the vector autoregressive (VAR) model for the Toda and Yamamoto test. To ascertain the order of integration, we apply the Augmented Dickey-Fuller (ADF) test. The tests are performed on a country-by-country basis. Table 1 reports the main results of the ADF test. It is shown that GDP per capita is integrated of order one for all countries, at the 5\% significance level. The ratio of FDI to GDP is integrated of order one for Cameroon, Congo, Cote d'Ivoire, Ghana, Nigeria, Senegal and South Africa while it is stationary in Angola, Kenya and Liberia, at 5\% level. Hence, for the ten countries, VAR models will add only one extra lag for the implementation of the causality tests.

\section{[Insert Table 1 Here]}

Following the modelling approach described earlier, we determine the appropriate lag length and compute the bounds F-statistics. Akaike and Schwarz Bayesian Information criteria are used to select the optimal order of lags to include in the unrestricted error correction models. Models are estimated for $p=0,1,2, \ldots, 6$. Table 2 provides results about the bounds tests F-statistic, optimal lags selected by AIC and SC, and Lagrange multiplier statistics for testing the hypothesis of no residual serial correlation against order 1 as denoted by $\chi^{2}(1)$. The Akaike and Schwarz information criteria selected lag orders ranked between 0 and 4 . The $\chi^{2}(1)$ statistics also suggest no serial correlation against order 1 for these lag lengths selected by AIC and SC.

The bounds test for cointegration involves the comparison of the computed F-statistics against the 5\% critical values, which are tabulated by Pesaran et al. (2001) or Narayan (2005). Table 2 shows that the F-statistic is higher than the upper bounds critical value for Angola and Cote d'Ivoire at the 5\% significance level and for Kenya at $10 \%$ level, when the dependent variable is GDP per capita in difference. For the seven other countries, namely, Cameroon, Congo, Ghana, Liberia, Niger, Senegal and South Africa, when the dependent variable is GDP per capita in difference, F-statistics lie below the lower bounds critical value. These econometric results indicate that there is a long-run relationship between FDI inflows and economic growth in three countries out of ten, which are Angola, Cote d'Ivoire and Kenya, when growth is the dependent variable. However, it is shown that there is a long-run relationship between FDI and growth at 0.05 in Liberia, Senegal and South Africa when the dependent variable is the ratio of FDI to GDP, because for these countries F-statistics are higher than 5\% upper-bound critical values.

[Insert Table 2 Here]

Consistent with the bounds test results, as summarized in table 2, we proceed to the estimation of the long-run relationship using equation (3), only in the case of the countries where a cointegrating relationship is established. Long-run effects of FDI on economic growth are provided by table 3. The Barden's equation results suggest statistically significant and negative error correction terms in the case of Angola, Cote d'Ivoire and Kenya, indicating that convergence to long-run equilibrium after a shock to FDI is very moderate for economic growth in Kenya and Cote d'Ivoire, and quite important for growth in Angola. For instance, the coefficient -0.56 (in the case of Angola) suggests that a deviation from the long-run equilibrium level of GDP in current year is corrected by about 56 percent in the next year. Moreover, long-run elasticities of FDI on economic growth are positive and significant at 5\% for Angola and Cote d'Ivoire, but it is not significant for Kenya. These results evidence that foreign direct investment inflows in Angola and Cote d'Ivoire are growth enhancing in the long-run. This positive long-run elasticity is also found by Adams (2009) using a panel data approach on 42 Sub-Saharan African countries including our sample with exception of Liberia; and by Balasubramanyam et al. (1996) testing for the Bhagwati's hypothesis (their sample includes Cote d'Ivoire, Ghana, Kenya and Nigeria), according to which the beneficial effect of FDI, in terms of enhanced economic growth, is stronger in those countries which pursue an outwardly oriented trade policy than it is in those countries adopting an inwardly oriented policy. However, Adams (2009) estimates the effect of FDI shares in GDP on real growth rates, and does not consider 
the presence of panel unit root in variables. Our long-run elasticities are higher than that evidenced by De Mello (1999) in the case of non-OECD countries including Cote d'Ivoire (0.01 and 0.03$)$, and vary within countries. Moreover, our results about Nigeria are supported by the work led by Akinlo (2004) who finds no significant effect of foreign capital on growth. Table 3 also indicates significant and negative error correction terms in the case of Liberia, Senegal and South Africa where high growth rate tend to promote FDI inflows. The FDI-led effect of growth is statistically significant in Senegal and South Africa, even if this effect seems very low in Senegal. In South Africa economic growth impacts FDI importantly.

[Insert Table 3 Here]

As previously mentioned, to set the stage for the Toda-Yamamoto test, the order of integration of the variables is initially determined using the augmented Dickey-Fuller (ADF) test. Then, we determine the appropriate lag structures to include in the vector autoregressive models using Akaike and Schwarz Bayesian Information Criteria. Table 4 reports the optimal lag orders and Wald statistics for the Toda and Yamamoto causality test. It is shown that the appropriate lag order is 4 in Angola, 5 in Cote d'Ivoire, 4 in Kenya, 2 in Liberia and South Africa.

We find that for the three countries where there is a long-run cointegrating relationship, i.e. Angola, Cote d'Ivoire and Kenya, FDI causes growth at the 5\% significance level. Furthermore, in Liberia and South Africa, economic growth causes FDI inflows at $10 \%$. These results are consistent with recent studies on the link between FDI and growth. For example, Hansen and Rand (2006) using data on 31 countries including Cameroon, Cote d'Ivoire, Ghana, Kenya, Nigeria and South Africa, show the existence of a bi-directional causality between GDP and FDI inflows. However, their results are based on mean group estimates. Hence, their conclusions are not country-specific.

\section{[Insert Table 4 Here]}

\section{Concluding remarks}

This study has contributed to the cointegrating and causal relationship between foreign direct investment and economic growth in the case of ten Sub-Saharan African countries. To this end, we use two recent econometric procedures which are the Pesaran et al. (2001) approach to cointegration and the procedure for non-causality test popularized by Toda and Yamamoto (1995). We build unrestricted error correction models and compute bounds F-statistics to test for the absence of a long-run relationship between foreign direct investment and growth. We also construct vector autoregressive models and compute modified Wald statistics to test for the non-causality between FDI and economic growth. Data are from the African Development Bank (2008), the World Bank (2008) and the UNCTAD (2008), and cover the period 1970-2007.

We show that there is a long-run relationship between foreign direct investment and economic growth in Angola, Cote d'Ivoire, Kenya, Liberia, Senegal and South Africa. In addition, the long-run effect of foreign direct investment on growth is positive and statistically significant in Angola and Cote d'Ivoire, but it is not significant in Kenya. Moreover, GDP impacts FDI significantly and positively in Senegal and South Africa. Conclusion about causality is that foreign direct investment significantly causes economic growth in Angola, Cote d'Ivoire and Kenya. In view of our findings, the conventional view which seems to suggest that the direction of causality runs from FDI to economic growth is confirmed in Angola, Cote d'Ivoire and Kenya, but not in Liberia and South Africa where growth causes FDI inflows.

The policy implications of our findings are straightforward. To maintain a sustainable economic growth, Angola, Cote d'Ivoire and Kenya have to be encouraged and supported to attract more foreign direct investment.

In further studies, attention needs to be given to the overall role of growth as a crucial determinant of FDI along with the quality of human capital, infrastructure, institutions, governance and tax systems in Sub-Saharan African countries.

\section{References}

Abdulai, D. N. (2007). Attracting foreign direct investment for growth and development in Sub-Saharan Africa: Policy options and strategic alternatives. Africa Development, XXXII, 1-23.

Adams, S. (2009). Foreign direct investment, domestic investment, and economic growth in Sub-Saharan Africa. Journal of Policy Modeling, doi:10.1016/j.jpolmod.2009.03.003.

African Development Bank. (2008). Selected Statistics on African Countries. African Development Bank, XXVII. 
Akinlo, A. E. (2004). Foreign direct investment and growth in Nigeria: An empirical investigation. Journal of Policy Modeling, 26, 627-639.

Balasubramanyam, V., Salisu, M. \& Sapsford, D. (1996). FDI and growth in EP and IS countries. Economic Journal, 106, 92-105.

Bardsen, G (1989). Estimation of long-run coefficients in error-correction models. Oxford Bulletin of Economics and Statistics, 51, 345-350.

Borensztein, E., De Gregorio, J. \& Lee, J-W. (1998). How does foreign direct investment affect economic growth? Journal of International Economics, 45, 115-135.

Busse, M. \& Hefeker, C. (2007). Political risk, institutions and foreign direct investment. European Journal of Political Economy, 23, 397-415.

Carkovic, M. \& Levine, R. (2003). Does foreign direct investment accelerate economic growth? University of Minnesota Working Paper, Minneapolis.

Cheung, Y-W. \& Lai, K. S., (1993). Finite-sample sizes of Johansen's likelihood ratio test for cointegration. Oxford Bulletin of Economics and Statistics, 55, 313-328.

Chowdhury, A. \& Mavrotas, G. (2006). FDI and growth: What causes what? World Economy, 29, 9-19.

De Mello, L. R. (1997). Foreign direct investment in developing countries and growth: A selective survey. Journal of Development Studies, 34, 1-34.

De Mello, L. R. (1999). FDI-led growth: Evidence from time series and panel data. Oxford Economic Papers, 51, 133-151.

Engle, R. F. \& Granger, C. W. J. (1987). Co-integration and error correction: Representation, estimation, and testing. Econometrica, 55, 251-276.

Gorg, H. \& Greenaway, D. (2004). Much ado about nothing? Do domestic firms really benefit from foreign direct investment? World Bank Research Observer, 19, 171-97.

Granger, C. W. (1986). Developments in the study of co-integrated economic variables. Oxford Bulletin of Economics and Statistics, 48, 213-228.

Hansen, H. \& Rand, J. (2006). On the causal links between FDI and growth in developing countries. World Economy, 29, 21-41.

Hanson, G. (2001). Should countries promote foreign direct investment? UNCTAD: G-24 Discussion Paper Series No. 9, UNCTAD, Geneva.

Harris, R. (1995). Using Cointegration Analysis in Econometric Modelling. London: Prentice Hall/Harvester Wheatsheaf.

Hsiao, C. \& Shen, Y. (2003). Foreign direct investment and economic growth: the importance of institutions and urbanization. Economic Development and Cultural Change, 51, 883-896.

Johansen, S. \& Juselius, K. (1990). Maximum likelihood estimation and inferences on cointegration with applications to the demand for money. Oxford Bulletin of Economics and Statistics, 52, 169-210.

Johansen, S. (1988). Statistical analysis of cointegration vectors. Journal of Economic Dynamics and Control, 12, 231-254.

Masih, A. M. M. \& Masih, R. (2000). The dynamics of fertility, family planning and female education in a developing economy. Applied Economics, 32, 1617-1627.

Mastromarco, C. \& Ghosh, S. (2009). Foreign capital, human capital, and efficiency: A stochastic frontier analysis for developing countries. World Development, 37, 489-502.

Narayan, P. K. \& Peng, X. (2007). Japan's fertility transition: Empirical evidence from bounds testing approach to cointegration. Japan and the World Economy, 19, 263-278.

Narayan, P. K. (2005). The relationship between saving and investment for Japan. Japan and the World Economy, 17, 293-309.

Pesaran, M. H. \& Shin, Y. (1999). An autoregressive distributed lag modelling approach to cointegration analysis. In S. Strom (Ed.), Econometrics and Economic Theory in the $20^{\text {th }}$ Century (Chapter 11). The Ragnar Frisch Centennial Symposium, Cambridge: Cambridge University Press. 
Pesaran, M. H., Shin, Y. \& Smith, R. J. (2001). Bounds testing approaches to the analysis of level relationships. Journal of Applied Econometrics, 16, 289-326.

Phillips, P. C. B. \& Toda, H. Y. (1993). Limit theory in cointegrated vector autoregressions. Econometric Theory, 9, 150-153.

Toda, H. Y. \& Yamamoto, T. (1995). Statistical inference in vector autoregressions with possibly integrated processes. Journal of Econometrics, 66, 225-250.

UNCTAD. (2008). World Investment Report 2008 Data. New York: United Nations Conference on Trade and Development, United Nations.

World Bank. (2008). 2008 World Development Indicators. Washington, D.C.: World Bank.

Yamada, H. (1998). A note on the causality between export and productivity: an empirical re-examination. Economics Letters, 61, 111-114.

Zhang, K. H. (2001). Does foreign direct investment promote economic growth? Evidence from East Asia and Latin America. Contemporary Economic Policy, 19, 175-185.

Table 1. Results for unit root tests

\begin{tabular}{|c|c|c|c|c|c|c|}
\hline \multirow{2}{*}{ Countries } & \multirow{2}{*}{ Samples } & \multicolumn{2}{|c|}{ Levels } & \multicolumn{2}{|c|}{ First differences } & \multirow{2}{*}{$d_{\max }$} \\
\hline & & $G D P C$ & $R F D I$ & $G D P C$ & $R F D I$ & \\
\hline Angola & $1970-2006$ & $-1.64(-3.59)$ & $-4.65^{*}(-2.95)$ & $-3.84^{*}(-3.59)$ & -- & 1 \\
\hline Cameroon & 1970-2007 & $-3.34(-3.55)$ & $-1.57(-2.95)$ & $-4.07^{*}(-3.54)$ & $-11.95^{*}(-2.95)$ & 1 \\
\hline Congo, Rep. & $1970-2007$ & $-2.11(-3.54)$ & $2.73(-2.96)$ & $-3.56^{*}(-3.54)$ & $-7.30^{*}(-2.96)$ & 1 \\
\hline Cote d'Ivoire & $1970-2007$ & $-2.65(-3.54)$ & $-0.51(-2.94)$ & $-4.02^{*}(-3.54)$ & $-6.14^{*}(-2.95)$ & 1 \\
\hline Ghana & $1970-2007$ & $-2.69(-3.56)$ & $1.25(-2.94)$ & $-4.96^{*}(-3.54)$ & $-4.58^{*}(-2.95)$ & 1 \\
\hline Kenya & $1970-2006$ & $-1.88(-3.54)$ & $-5.43^{*}(-2.95)$ & $-4.81^{*}(-3.54)$ & -- & 1 \\
\hline Liberia & 1970-2006 & $-1.71(-2.95)$ & $-5.71^{*}(-2.94)$ & $-3.19^{*}(-2.95)$ & -- & 1 \\
\hline Nigeria & $1970-2007$ & $-3.40(-3.55)$ & $-0.50(-2.94)$ & $-3.96^{*}(-3.55)$ & $-8.11^{*}(-2.95)$ & 1 \\
\hline Senegal & $1970-2007$ & $0.30(-2.94)$ & $-1.27(-2.95)$ & $-6.34^{*}(-3.54)$ & $-13.00^{*}(-2.95)$ & 1 \\
\hline South Africa & $1970-2007$ & $-2.44(-3.54)$ & $-0.44(-2.95)$ & $-4.31^{*}(-3.54)$ & $-7.39^{*}(-2.95)$ & 1 \\
\hline
\end{tabular}

Notes: ${ }^{*}$ denotes rejection of the null hypothesis of unit root the at $5 \%$ level. Critical values at 0.05 are in parenthesis. GDPC and RFDI are GDP per capita and the ratio of FDI inflows to GDP, respectively. 
Table 2. Bounds test F-statistics. Sample: 1970-2007

\begin{tabular}{|c|c|c|c|c|c|}
\hline Countries & $\begin{array}{c}\text { Endogenous } \\
\text { variable }\end{array}$ & Lags & $\chi^{2}(1)$ & F-statistic & Outcome \\
\hline \multirow[t]{2}{*}{ Angola } & $\triangle G D P C$ & 3 & 0.02 & 26.50 & Cointegration at 0.05 \\
\hline & $\triangle R F D I$ & 3 & 0.07 & 3.24 & No cointegration \\
\hline \multirow[t]{2}{*}{ Cameroon } & $\triangle G D P C$ & 1 & 0.11 & 4.65 & No cointegration \\
\hline & $\triangle R F D I$ & 1 & 0.03 & 2.32 & No cointegration \\
\hline \multirow[t]{2}{*}{ Congo, Rep. } & $\triangle G D P C$ & 1 & 0.001 & 1.62 & No cointegration \\
\hline & $\triangle R F D I$ & 1 & 1.67 & 3.33 & No cointegration \\
\hline \multirow[t]{2}{*}{ Cote d'Ivoire } & $\triangle G D P C$ & 4 & 0.01 & 9.25 & Cointegration at 0.05 \\
\hline & $\triangle R F D I$ & 0 & 0.19 & 1.96 & No cointegration \\
\hline \multirow[t]{2}{*}{ Ghana } & $\triangle G D P C$ & 0 & 1.03 & 1.91 & No cointegration \\
\hline & $\triangle R F D I$ & 1 & 0.11 & 3.57 & No cointegration \\
\hline \multirow[t]{2}{*}{ Kenya } & $\triangle G D P C$ & 4 & 0.25 & 6.70 & Cointegration at 0.10 \\
\hline & $\triangle R F D I$ & 0 & 0.19 & 0.71 & No cointegration \\
\hline \multirow[t]{2}{*}{ Liberia } & $\triangle G D P C$ & 1 & 2.24 & 1.33 & No cointegration \\
\hline & $\triangle R F D I$ & 0 & 0.02 & 16.18 & Cointegration at 0.05 \\
\hline \multirow[t]{2}{*}{ Nigeria } & $\triangle G D P C$ & 4 & 0.64 & 0.15 & No cointegration \\
\hline & $\triangle R F D I$ & 0 & 0.80 & 3.52 & No cointegration \\
\hline \multirow[t]{2}{*}{ Senegal } & $\triangle G D P C$ & 3 & 0.05 & 0.72 & No cointegration \\
\hline & $\triangle R F D I$ & 0 & 0.85 & 20.76 & Cointegration at 0.05 \\
\hline \multirow[t]{2}{*}{ South Africa } & $\triangle G D P C$ & 0 & 1.96 & 2.44 & No cointegration \\
\hline & $\triangle R F D I$ & 0 & 0.01 & 24.46 & Cointegration at 0.05 \\
\hline
\end{tabular}

Notes: $\chi^{2}(1)$ is an LM statistic for testing no residual serial correlation against order 1. GDPC and RFDI are GDP per capita and the ratio of FDI inflows to GDP, respectively. $\Delta$ is the difference operator.

Table 3. Estimated long-run coefficients of FDI, Sample: 1970-2007.

\begin{tabular}{lccc}
\hline \multicolumn{1}{c}{ Countries } & Endogenous variable & EC(-1) & Long-run effects \\
\hline Angola & $G D P C$ & $-0.56^{\dagger}(-5.72)$ & $0.60^{\dagger}(2.40)$ \\
Cameroon & & -- & -- \\
Congo, Rep. & & -- & -- \\
Cote d'Ivoire & $G D P C$ & $-0.36^{\dagger}(-4.10)$ & $1.76^{\dagger}(6.73)$ \\
Ghana & & -- & -- \\
Kenya & $G D P C$ & $-0.05^{\dagger}(-3.66)$ & $3.25(1.60)$ \\
Liberia & $R F D I$ & $-0.98^{\dagger}(-5.69)$ & $0.08(0.80)$ \\
Nigeria & & -- & -- \\
Senegal & $R F D I$ & $-1.12^{\dagger}(-6.44)$ & $0.07^{\dagger}(4.55)$ \\
South Africa & $R F D I$ & $-1.18^{\dagger}(-6.93)$ & $1.18^{\dagger}(3.72)$ \\
\hline
\end{tabular}

Notes: ${ }^{a} \mathrm{EC}(-1)$ is the coefficient estimate for the lagged error correction term. ${ }^{\dagger}$ indicates significance at the $5 \%$ level. Numbers in parenthesis are t-statistics. GDPC and RFDI are GDP per capita and the ratio of FDI inflows to GDP, respectively. 
Table 4. Toda and Yamamoto non-causality test results, Sample: 1970-2007

\begin{tabular}{|c|c|c|c|c|c|}
\hline \multirow{2}{*}{ Countries } & \multirow{2}{*}{ Lags } & \multicolumn{2}{|c|}{ RFDI doesn't cause GDPC } & \multicolumn{2}{|c|}{ GDPC doesn't cause RFDI } \\
\hline & & Wald Statistic & P-value & Wald Statistic & P-value \\
\hline Angola & 4 & $20.23^{*}$ & 0.00 & 4.02 & 0.40 \\
\hline Cameroon & 1 & 2.52 & 0.11 & 1.26 & 0.26 \\
\hline Congo, Rep. & 2 & 0.51 & 0.77 & 0.72 & 0.70 \\
\hline Cote d'Ivoire & 5 & $20.39^{*}$ & 0.00 & 1.79 & 0.18 \\
\hline Ghana & 1 & 0.52 & 0.47 & 0.36 & 0.55 \\
\hline Kenya & 4 & $10.43^{*}$ & 0.03 & 5.14 & 0.27 \\
\hline Liberia & 2 & 0.07 & 0.97 & 4.72 & $0.09^{* *}$ \\
\hline Nigeria & 1 & 2.22 & 0.14 & 0.34 & 0.56 \\
\hline Senegal & 1 & 0.0002 & 0.98 & 0.28 & 0.59 \\
\hline South Africa & 2 & 0.73 & 0.69 & 5.05 & $0.08^{* *}$ \\
\hline
\end{tabular}

Notes: ${ }^{*}$ indicates rejection of the null at the $5 \%$ level. ${ }^{* *}$ indicates rejection of the null at the $10 \%$ level. GDPC and RFDI are GDP per capita and the ratio of FDI inflows to GDP, respectively. 